\title{
Turkish EFL Teachers' Perceptions and Practices of Foreign Language Assessment in Primary Education
}

\author{
Yasemin Kirkgoz ${ }^{1}$ \\ Muzaffer Pinar Babanoglu² \\ Reyhan Ağçam ${ }^{3}$ (D) \\ ${ }^{1}$ Çukurova University, Adana, Turkey \\ 'E-mail:ykirkgoz@cu.edu.tr.Tel:+903223386060 \\ ${ }^{2,3}$ Kahramanmaraş Sütçü İmam University, Kahramanmaraş, Turkey \\ E-mail:pinarbab@hotmail.com Tel: +90344.3001463 \\ ${ }^{s}$ E-mail: reyhanagcam@gmail.com Tel:+90344.3001316
}

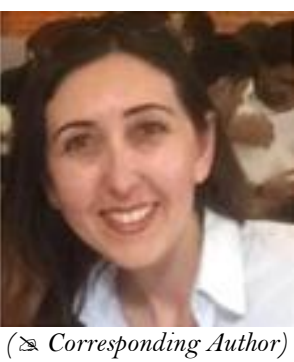

\begin{abstract}
The present study aimed to investigate perceptions of EFL teachers working at state primary schools on core language skills, assessment types and question types used in assessing student's foreign language development and proficiency during an academic year. Data were gathered from 56 EFL teachers working at 42 primary state schools in Turkey through a questionnaire comprising a variety of items to elicit their perceptions and applications of language assessment in the classes of 4th to 6th graders. Results obtained from frequency analyses indicated that the penand-paper tests, performance tasks, and in-class observation are the mostly used assessment tools, and that the selected response items are mostly employed question types in the tests, and that performance-based and communication-based assessment types are preferred more frequently than the traditional types in evaluating students' success in learning EFL.
\end{abstract}

Keywords: Assessment, English as a foreign language (EFL), Primary education.

Citation | Yasemin Kirkgoz; Muzaffer Pinar Babanoglu; Reyhan Ağçam (2017). Turkish EFL Teachers' Perceptions and Practices of Foreign Language Assessment in Primary Education. Journal of Education and e-Learning Research, 4(4): 163-170.

History:

Received: 13 December 2017

Revised: 28 December 2017

Accepted: 3 January 2018

Published: 8 January 2018

Licensed: This work is licensed under a Creative Commons

Attribution 3.0 License (cc) $\mathrm{Er}$

Publisher:Asian Online Journal Publishing Group
Contribution/Acknowledgement: All authors contributed to the conception and design of the study.

Funding: This study received no specific financial support

Competing Interests: The authors declare that they have no conflict of interests.

Transparency: The authors confirm that the manuscript is an honest, Transparency: The authors confirm that the manuscript is an honest,
accurate, and transparent account of the study was reported; that no vital accurate, and transparent account of the study was reported; that no vital
features of the study have been omitted; and that any discrepancies from the features of the study have been omitted;
study as planned have been explained.

Ethical: This study follows all ethical practices during writing.

\section{Contents}

1. Introduction

2. Theoretical Background

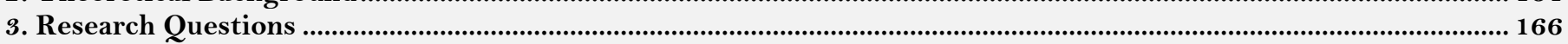

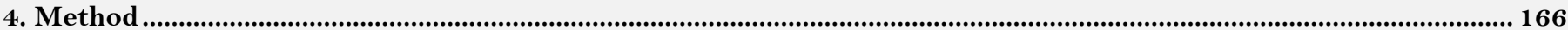

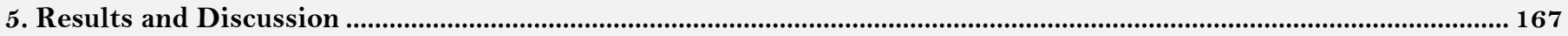

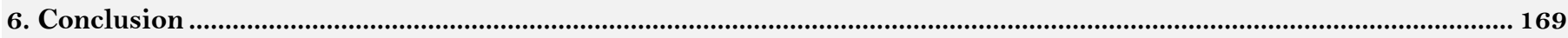

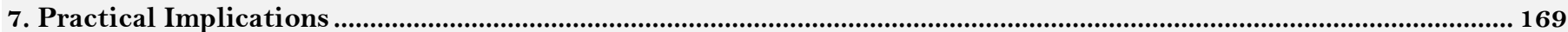

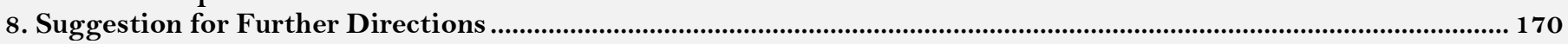

References 


\section{Introduction}

Assessment is a wide range of activities that involve gathering and examining data for the purpose of improving teaching and learning (Halpern et al., 1993). More specifically, it is defined as 'the process of collecting information about a student to aid in decision making about the progress and language development of the student' (Cheng et al., 2004). According to Dunn et al. (2004) it is conducted to show whether or not the learning has been successful, or to clarify the expectations of the teachers from the students. Angelo (1995) proposes that assessment is an ongoing process aiming to understand and improve students' learning and describes its functions as; (i) making expectations explicit and public; (ii) setting appropriate criteria and high standards for learning quality; (iii) systematically gathering, analysing, and interpreting evidence to determine how well performance matches those expectations and standards, and (iv) using the ultimate information to document, explain, and improve performance. According to Rea-Dickens (2000) the process serves several other functions as (i) acting a diagnostic tool that provides feedback to the teacher about students' progress and their attainment of curriculum objectives; (ii) helping the teachers determine students' strengths and weaknesses to guide the teacher to realize educational improvements, and (iii) assisting teachers and educational authorities judge the effectiveness of teaching and learning. The present study aims to explore the perceptions and practices of assessment in primary foreign language classrooms in Turkey. It primarily investigates perceptions of EFL teachers working at state primary schools on core language skills, assessment types and question types used in assessing student's foreign language development and proficiency during an academic year.

\section{Theoretical Background}

\subsection{Assessment Types}

In order to improve learning, the assessment focuses on to what extent students successfully learn what is provided to them during classes. The methodology of assessment runs to achieve learning objectives and to measure learning outcomes described in the curricula taking into consideration whether they have been thoroughly achieved. The processing steps of assessment could be outlined as (I) establishing learning goals (establishing clear, measurable expected outcomes of student learning); (ii) providing learning opportunities (ensuring that students have sufficient opportunities to achieve those goals); (iii) assessing students' learning (systematically gathering, analysing and interpreting evidence to determine how well student learning matches the goals); and (iv) using the results (to evaluate students' progress). Two main ways to gather these learning outcomes are formative and summative assessment types.

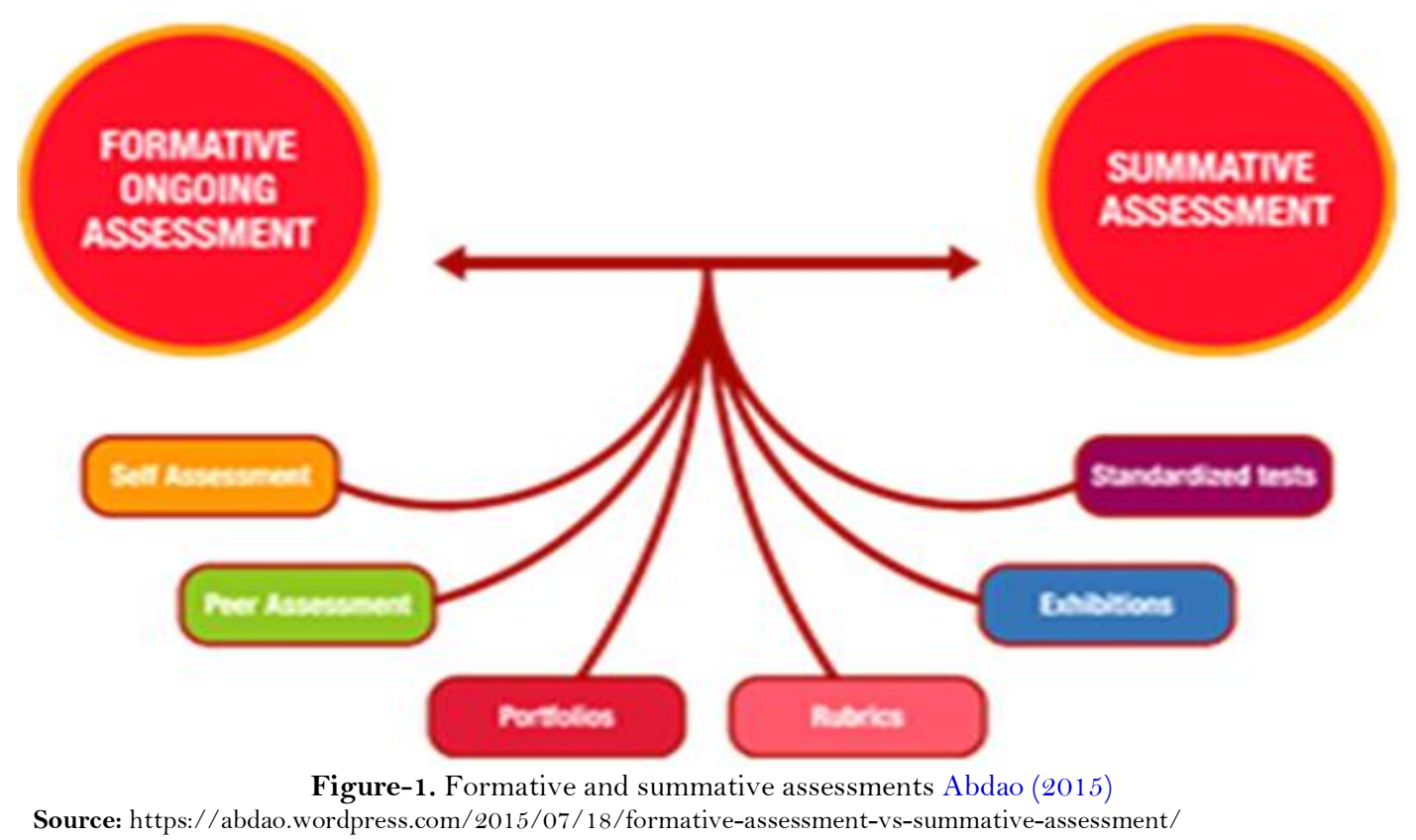

As can be seen in Figure 1, formative assessment is applied during learning whereas summative assessment is undertaken at the end of the course or the program. The assessment types commonly used in foreign language assessment especially in Turkish state primary schools include in-class performance, oral exams, pen-and-paper exams, quizzes, performance tasks, portfolios, oral presentations, and project assignments. During the procedure, improvement of students' core linguistic skills is expected to be measured by the teachers (i.e. grammar, listening, reading, speaking, vocabulary and writing). The written exams administered by these teachers typically include the following question types: fill-in items, matching items, multiple choice items, true-false questions, wh- questions, and yes-no questions (Kırkgöz and Ağçam, 2012).

Brown and Hudson (1998) categorize response assessment types into three groups as (I) Selected Response which requires examines to choosing from a number of options (i.e. true-false, matching, multiple-choice, and etc.); (ii) Constructed Response (i.e. sentence completion, writing an essay, providing short and long answers, and etc.); and (iii) Personal Response (i.e. self- and/or peer assessment or portfolio assessment). The proper choice of assessment type primarily involves realistic and meaningful planning in order to attain the course objectives. Student learning outcomes are driven from the objectives related to the goals and mission of the program. An Assessment Plan must include all these components and focus on the assessment of each learning outcome and how the evaluation of assessment results is used for program improvement.

\subsection{EFL Assessment in Turkey}

Due to the certain policy changes after the 1997 education reform in Turkey, which has a great impact on 
English Language Teaching at all levels, major innovative attempts have been done at the level of assessment and testing systems in primary education (Kırkgöz, 2007; Haznedar, 2010). However, the testing system has still been in the axis of traditional pencil-paper level and the theory of assessment is considered as only a document that determines the knowledge of language structures and their functions to be learnt by the students (Haznedar, 2012). Kırkgöz (2007) claims that traditional paper and pencil tests, which are extensively used in Turkish schools, are no longer appropriate assessment tools and that they must be replaced by performance-based assessment types such as portfolios, which are more congruent with the principles of communicative language teaching method.

The Report on Turkey National Needs Assessment of State School English Language Teaching prepared by the British Council in cooperation with TEPAV (The Economic Policy of Research Foundation of Turkey) in 2014 has indicated that English is taught as a subject at Turkish state schools rather than a language of communication. In the report, this finding is identified as one of the five major factors that 'lead to the failure of Turkish students to speak and understand English on graduation from High School'. The following are the other factors acknowledged in the report in concern: (I) teacher-centred/ textbook-centred learning and grammar based testing, (ii) classroom management, (iii) lack of differentiation regarding needs, interests, levels of students, and (iv) rigidity of the inspectorate. Our study is intended to scrutinize whether this is the case in the primary schools located in one province of Turkey which is located in the southern part.

\subsection{Educational Perceptions and Practices}

The term perception has been similarly defined by various psychologists across decades. Namely, it was defined as a process by which organisms interpret and organize sensation to produce a meaningful experience of the world (Lindsay and Norman, 1977). More than three decades later, it was re-defined as a process a process by which individuals organise and interpret their sensory emotions in order to give meaning to their environments (Robbins, 2009). Likewise, Bernstein et al. (2012) suggest that it is a process through which sensations are interpreted, using knowledge and understanding of the world, so that they become meaningful experiences. More specifically, Gould (2014) identified it as the subsequent selection, organization, and interpretation of sensory input -it is the process of obtaining information about both the external and internal environments, which results, via integration utilizing memory, in the conscious experience, recognition, and interpretation of objects, object relationships, and events. In a similar vein, Wood (2013) underlines that is not a simple matter of receiving external reality, and that we invest a lot of energy in constructing the meaning of phenomena. According to her, it consists of three interactive processes: (I) selecting, (ii) organizing, and (iii) interpreting, and is influenced by such factors as physiological state, individual expectations, age, and culture. Since it specifically falls within the scope of psychology, it will not be discussed here in more detail. Instead, its role in educational concerns will be briefly mentioned. Könings et al. (2014) propose that teachers and students have their own perceptions of education, and that congruent perceptions contribute to optimal teaching-learning processes and help achieving best learning outcomes. Based on the findings of their experimental study, Goldstone et al. (2008) concluded that instruction in science and mathematics should involve not only teaching abstract rules and equations but also training students to perceive and interact with their world. In a recent study, Grobgeld et al. (2016) investigated role perception among faculty members working at teacher education colleges to help formulate an official role definition for them. They are of the opinion that formulation of such definition is significant for enabling them to understand how and with whom they interact and how to meet the goals required of them. The researchers also contend that a clear and complete definition of the role will help new faculty find their bearings within the organization sooner, as will facilitate their transition into the role of teacher educators. In his book published in 1992, Marzano (1992) underlines the significance of perceptions and attitudes in classroom environment noting that,

"More recently, psychologists have begun to view classroom climate more as a function of the attitudes and perceptions of the learner than of elements external to the learner. If students have certain attitudes and perceptions, they have a mental climate conducive to learning. If those attitudes and perceptions are not in place, learners have a mental climate not conducive to learning. In general, two types of attitudes and perceptions affect learners' mental climate: a sense of acceptance and a sense of comfort and order".

An educational practice, on the other hand, refers to a set of established activities or procedures that are normally or regularly carried out in association with an educational task (Spector and Yuen, 2016). In a broader sense, Horner et al. (2005) define it as an educational approach, system change, curricular or behavioural intervention implemented with an expectation of measurable educational, behavioural or physical benefit. Benitez et al. (2015) maintain that knowledge of educational practice refers to the whole repertoire of possible practices, from which students are able to choose, but also their advantages and limitations, and that these practices include participating in discussions and being punctual in completing assignments. From the perspectives of teachers, Elmore (1996) identifies the core of educational practice how teachers understand the nature of knowledge and the student's role in learning, and how these ideas about knowledge and learning are manifested in teaching and classwork. In the light of the above-mentioned literature, educational practices are considered to be indispensably influenced by perceptions of teachers as well as students. The following section is intended to offer research previously conducted on perceptions and practices of assessment at various educational levels.

\subsection{Previous Studies}

The literature has been reviewed in order to ground the present study, and to compare the newly elicited findings with those reported in previous studies. It has been seen that most of the previous research has been concentrated on teachers' perceptions (or beliefs) of assessment and/ or their assessment practices at various proficiency levels. For instance, Chan (2007) conducted a large scale study on beliefs and practices of 520 EFL teachers working at elementary schools in Northern Taiwan about multiple assessments. The researcher reported that the teachers believed that multiple assessments were more practical than traditional pen-and-paper tests which are the mostly used assessment type in the country. Similar results were found by Yung (2008) in a further study. Gattullo (2000) investigated formative assessment types in a teacher-pupil interaction based classroom study with the participation of a research group, and concluded that teachers tend to employ such types of assessment as 
correcting, judging, and questioning in their classes. Saad et al. (2013) examined Iranian EFL teachers' beliefs on assessment, and suggest that teachers do not play a significant role in the process because of top-down managerial approaches toward assessment and national educational system of the country. Likewise, Al-Nouh et al. (2014) studied alternative assessment types employed by primary EFL teachers in Kuwait, and found that the teachers in concern mostly preferred conventional assessment types rather than alternative ones.

In respect of EFL assessment in Turkey, Haznedar (2010) conducted a large scale project on the reforms introduced in the field of EFL in Turkey. Her data came from over 500 EFL teachers working at primary schools via surveys focusing on teaching and testing methods and techniques they prefer to use in their teaching to young learners. The results of the study related to the teachers' assessment practices are as follows: [Written exam (98.9\%); Oral exam (51.4\%); Exercise (81.2\%); True/False Questions (69.8\%); Multiple-Choice (78.2\%); and Portfolios $(30.8 \%)$. She found that written exams are still the mostly used assessment type, and that portfolios are preferred by only $30 \%$ of the teachers. Exercises constitute the other category which was highly preferred by the teachers, followed by multiple choice and true/false questions. However, the researcher points out that these shortterm procedures for evaluation of students' knowledge are no longer accepted in the fields of education, and advocates that they should be replaced with long-term extended and systematic assessment types which are more reliable and purposeful such as homework and project assignments.

In a comparative study in Turkey, Kırkgöz and Ağçam (2012) investigated the written assessment practices of young English language learners attending state primary schools with a focus on comparing the question types applied by the teachers prior to and following the 2005 curriculum innovation in English language teaching (ELT) in primary education in Turkey. They identified the teachers' written assessment practices, over 100 written examination papers collected from 25 teachers who had been teaching in $4^{\text {th }}$ and $5^{\text {th }}$ grades since 1997 , and analysed them with regard to the question types based on the categorization suggested by Brown and Hudson (1998). Their findings indicated no major differences between the types of questions used in the written tests prior to and following the 2005 curriculum innovation, and that constructed response were employed much more frequently than selected response items in written tests.

$\ddot{O}_{z}(2014)$ suggests that most of Turkish EFL teachers heavily rely on conventional methods rather than formative assessment tools such as self-assessment and peer assessment. On the contrary, another study conducted by Birgin and Baki (2009) who surveyed perceptions of primary school Turkish EFL teachers on alternative assessment types revealed top-five assessment types proficiently used by the teachers are classroom observation, homework assignments, presentations, performance tasks and class discussions.

\section{Research Questions}

In order to investigate perceptions of EFL teachers on assessment, assessment types, assessment of linguistic skills and the question types used in written tests in Turkish state primary schools, four research questions were posed.

1. What are the perceptions of EFL teachers on language testing and assessment in primary education in Turkey?

2. What assessment types are used by EFL teachers in language testing and assessment in primary education in Turkey?

3. What are the perceptions of EFL teachers on core language skills in language testing and assessment in primary education in Turkey?

4. What types of questions are used by EFL teachers in language testing and assessment in primary education in Turkey?

The following section offers methodological outline of the study.

\section{Method}

\subsection{Participants}

Data of the study were gathered from 56 EFL teachers working at 42 state primary schools in a province in Turkey. The majority of the participants were female (84\%). They had an average of 12 years of experience in teaching English as a foreign language. At the time of the study (Academic year 2014-2015), they had an average weekly workload of 22 class hours.

\subsection{Data Collection and Analysis}

For data collection, a questionnaire including multiple choice items, three-point Likert-type items and openended statements were developed by the researchers, and the expert opinion was obtained from two faculty members who are specialised in testing and assessment. The questionnaire was finalised based on the expert feedback on the items, and administered to the participants to reveal their perceptions on the applications of foreign language assessment in primary education. The first part of the questionnaire was intended to investigate teachers' opinions about the significance of assessment for the students. Namely, teachers were asked whether they believe testing and assessment are needed in foreign language education, whether they revise their lesson plans after the exams when complete success has not been attained, how often they assign homework to the students, and whether the students' interests in these assignments are taken into account in the course of assessing their success. In the second part of the questionnaire, the participants were required to list core language skills in order of significance in the assessment process (e.g. grammar, listening, reading, speaking, vocabulary and writing). The items were pointed from "very significant" to "might be ignored". The third part was designed to reveal assessment types employed by these teachers who were asked to choose among nine items (e.g. pen and paper exams, quizzes, performance tasks, portfolio, in-class observation, projects, oral exams, presentations, and other). In the last part, teachers were kindly asked to report the item types they used in written and oral exams in their classes, and to rank the identified item types (e.g. Fill in the Blank, Matching, Multiple Choice, True/ False, Translation, WhQuestions, Yes/ No Questions, and other) from most to least significant in order to reveal their predispositions. 
The questionnaire was conducted in two ways. The teachers working at the schools located in the city centre were visited at their workplace on a scheduled date and time, and requested to fill out the related form. The other teachers were emailed the form, and asked to send it back after completion. The elicited data were analysed both quantitatively and qualitatively. Frequency calculation was used for quantitative data analysis, and content analysis method (Mayring, 2000) was utilized in analysing the responses given to the open-ended items. It is significant to note that satisfactory inter-rater reliability was obtained among the researchers. The following section offers analysis results and related discussion on them.

\section{Results and Discussion}

Results of the study were evaluated in two perspectives: (i) perceptions of EFL teachers on the necessity of assessment in primary foreign language education, and the significance of core language skills in language testing and assessment in primary education in Turkey (Research Questions 1 and 3, and (ii) their assessment practices in foreign language classes (e.g. assessment and item types) (Research Questions 2 and 4).

\subsection{Perceptions of EFL Teachers on Assessment in Foreign Language Education}

The first question of the survey was intended to elicit teachers' opinions as to whether assessment is necessary in foreign language education. Not surprisingly, most of them responded positively (90\%) while no one remained neutral about it. As a follow up query, they were requested to discuss the purpose of assessment in foreign language education. The following are the most popular reasons proposed by them:

- To track foreign language development of students,

- To check whether the subject matters have been understood,

- To see whether the goals and objectives stated in the curriculum have been achieved, and to improve/ change the curriculum (or lesson plans) in case of a failure,

- To evaluate both teachers' and students' performance in the language classroom,

- To increase the quality of education,

- To inform students about their own learning,

- To evaluate the efficacy of the approaches, methods and/ or techniques used in the language classroom, and to make related changes in case of a failure.

- They informed that the procedure is typically performed by EFL teachers in a number of ways identified in the related annual plan.

Over $90 \%$ of them informed that they revise their lesson plans according to (undesired) exam results of the students. The following are the implementations reported by a couple of teachers.

"I usually go over the subject matter which has not been understood well."

"I usually try to teach the subject matter students have failed to learn using different approaches, methods or techniques."

"I sometimes give hand outs to the students or come up with more examples in order to reinforce the challenging grammatical structures they seem to have difficulty in understanding."

As for homework assignment, all the participants stated that they regularly assign homework to their students, which is in line with the results previously reported in Birgin and Baki (2009). As for the purpose of homework assignment, they identified the following reasons.

- To have students regurgitate the subject matter,

- To reinforce the newly gained knowledge having students practice it,

- To encourage students to take responsibility in their own learning,

- To help students understand the subject matters more efficiently,

- To have students get prepared for the next class,

- To maintain students' knowledge (helping them transfer what exists in the short term memory to long term memory)

- To encourage students to search and investigate, which is likely to increase their in-class performance,

- To keep students engaged with the language outside the classroom,

Approximately all participants stated that they take their students' interest in homework assignments as well as their in-class performance into consideration in their EFL assessment. One of them noted that she might ignore trivial errors (e.g. spelling, punctuation errors) on the exam paper of the students who perform notably well in the classroom. Subsequently, they were required to evaluate the significance of core language skills in foreign language education. In order to investigate their perceptions on core linguistic skills in the assessment of students' progress in foreign language, teachers were required to identify the necessity of each skill using a three-point scale composing 'very significant', 'partially significant' and 'might be ignored'. It is noteworthy that the participants were not supposed to choose among the skills in concern; instead, they were asked to evaluate each skill in its own right. Table 1 illustrates related findings.

Table-1. Teachers' perceptions on linguistic skills in foreign language education

\begin{tabular}{l|l|l|l|l|l|l}
\hline \multirow{2}{*}{ Skills } & \multicolumn{2}{l}{ Very significant } & \multicolumn{2}{l}{ Partially significant } & \multicolumn{2}{l}{ Might be ignored } \\
\cline { 2 - 7 } & $\boldsymbol{f}$ & $\mathbf{\%}$ & $\boldsymbol{f}$ & $\mathbf{\%}$ & $\boldsymbol{f}$ & \% \\
\hline Grammar & 22 & 39.23 & 16 & 28.57 & 18 & 32.14 \\
\hline Listening & 15 & 26.79 & 9 & 16.07 & 32 & 57.14 \\
\hline Reading & 14 & 25.0 & 26 & 46.43 & 16 & 28.57 \\
\hline Speaking & 27 & 48.21 & 9 & 16.07 & 20 & 35.71 \\
\hline Vocabulary & 29 & 51.79 & 17 & 30.36 & 10 & 17.86 \\
\hline Writing & 5 & 8.93 & 35 & 62.50 & 16 & 28.57 \\
\hline
\end{tabular}

Source: The findings are originally driven from data analysis in this study. 
In accordance with the findings, it is seen that the teachers consider all skills except listening very significant or partially significant in assessing foreign language development of their students. As seen in Table 1, vocabulary was the skill mostly reported by teachers as very significant in assessing students' progress in foreign language, followed by speaking which was reported by 27 out of 56 teachers (48.2\%). Taking into consideration the structure of the nationwide tests administered to the students attending state primary schools in the country at the end of each academic year, it was surprising to see that the grammar was found very significant by fewer teachers as opposed to vocabulary and speaking. The tests in question are essentially designed to measure students' proficiency in foreign language on the basis of their progress in reading, grammar, and vocabulary skills resulting in a foreign language learning environment whereby relatively more interactive and productive skills (i.e. listening, speaking and writing) are mostly ignored by the teachers. Not surprisingly, on the other hand, $57 \%$ of the teachers reported that listening might be ignored during the assessment process. Likewise, approximately $36 \%$ of the participants informed that speaking might also be ignored in the procedure, and it is equally striking that those who identified assessing writing as very significant constituted minority. This might primarily stem from the above-mentioned structure of the tests conducted in Turkey. In other words, different results would be expected concerning teachers' perceptions on the assessment of students' proficiency in such skills as listening and writing provided they were also measured in those tests.

\subsection{Foreign Language Assessment Practices of EFL Teachers}

In order to reveal EFL teachers practices of foreign language assessment, they were provided nine assessment types including the options oral exam, presentation, portfolio, project, quiz, in-class performance, performance task, pen-and-paper exam, and other, and asked to choose the ones they employ in assessing their students' progress in foreign language education. Table 2 is intended to display the related results.

Table-2. Teachers' assessment practices in foreign language education

\begin{tabular}{l|l|l}
\hline Assessment Types & $\boldsymbol{f}$ & $\mathbf{\%}$ \\
\hline Oral Exam & 18 & 32.14 \\
\hline Presentation & 25 & 44.64 \\
\hline Portfolio & 31 & 55.36 \\
\hline Project & 40 & 71.43 \\
\hline Quiz & 46 & 82.14 \\
\hline In-class Performance & 51 & 91.07 \\
\hline Performance Task & 55 & 98.21 \\
\hline Pen-and-paper Test & 56 & 100.00 \\
\hline
\end{tabular}

It was an expected finding that pen-and-paper tests were employed by all teachers since they are a compulsory part of assessment process in primary education in Turkey. What is surprising and pleasing was to see that performance tasks are used by all teachers except one, and that in-class performance of students are taken into consideration by over $90 \%$ of the teachers in assessing students' progress in foreign language education. Likewise, it is interesting to conclude that such assessment types as projects, portfolios and presentation which are intended to measure students' communicative skills as well as to encourage them to express themselves in public are also included into the process. Namely, they were reported by approximately half of the participants. These findings remarkably contradict with the ones reported in most of the existing literature (Chan, 2007; Yung, 2008; Haznedar, 2010; Saad et al., 2013; Al-Nouh et al., 2014; Öz, 2014) while approving Birgin and Baki (2009).

Finally, the participant teachers' choices of question types in their written assessment were elicited. They were provided with a list of question types proposed by Brown and Hudson (1998) and asked to state how often they use each in their written assessment. It is noteworthy that the category of personal response assessment was not investigated in this particular part of the study since its aim is restricted to reveal the question types used in written assessment of the teachers. Therefore, only the question types falling into the categories of selected response assessment and constructed response assessment were presented to them in the survey. Findings related to selected response items are presented in Table 3.

Table-3. SRIs in written assessment practices of EFL teachers

\begin{tabular}{l|l|l|l|l|l|l}
\hline \multirow{2}{*}{ Item Type } & \multicolumn{2}{l}{ Always/ Usually } & \multicolumn{2}{l}{ Occasionally } & \multicolumn{2}{l}{ Seldom/ Never } \\
\cline { 2 - 7 } & $\boldsymbol{f}$ & $\mathbf{\%}$ & $\boldsymbol{f}$ & $\mathbf{\%}$ & $\boldsymbol{f}$ & $\mathbf{\%}$ \\
\hline Matching & 18 & 32.14 & 29 & 51.79 & 9 & 16.07 \\
\hline Multiple Choice & 15 & 26.79 & 15 & 26.79 & 26 & 46.43 \\
\hline True/ False & 8 & 14.29 & 24 & 42.86 & 24 & 42.86 \\
\hline
\end{tabular}

As demonstrated in Table 3, multiple choice items and T-F items are not preferred as frequently as matching items by the teachers in their written assessment, partially contradicting Haznedar (2010). Considering that the latter requires more cognitive effort, this could be evaluated as a pleasing result. Table 4 displays the frequency distribution of constructed response items used by the teachers.

Table-4. CRIs in written assessment practices of EFL teachers

\begin{tabular}{l|l|l|l|l|l|l}
\hline \multirow{2}{*}{ Item Type } & \multicolumn{2}{|l|}{ Always/ Usually } & \multicolumn{2}{l}{ Occasionally } & \multicolumn{2}{l}{ Seldom/ Never } \\
\cline { 2 - 7 } & $\boldsymbol{f}$ & $\mathbf{\%}$ & $\boldsymbol{f}$ & $\mathbf{\%}$ & $\boldsymbol{f}$ & $\mathbf{\%}$ \\
\hline Fill-in & 37 & 66.07 & 15 & 26.79 & 4 & 7.14 \\
\hline Translation & 1 & 1.79 & 8 & 14.29 & 47 & 83.93 \\
\hline Wh- Q & 49 & 87.50 & 7 & 12.50 & 0 & 0.00 \\
\hline Yes/ No & 7 & 12.50 & 24 & 42.86 & 25 & 44.64 \\
\hline Other (Labelling) & 2 & 3.57 & 0 & 0.00 & 0 & 0.00 \\
\hline
\end{tabular}


Wh-Questions and fill-in items revealed the mostly used constructed response items by the teachers. Yes-no questions tend to be occasionally preferred in the written assessment of foreign language education. Translation items are inclined to be never or seldom preferred in the process in concern. Table 5 depicts the distribution of selected response items and constructed response items over teachers' preferences in their written assessment.

Table-5. SRIs and CRIs in written assessment practices of EFL teachers

\begin{tabular}{|c|c|c|c|c|c|c|}
\hline \multirow[t]{2}{*}{$\overline{\text { Item Type }}$} & \multicolumn{2}{|c|}{ Always/Usually } & \multicolumn{2}{|c|}{ Occasionally } & \multicolumn{2}{|c|}{ Seldom/ Never } \\
\hline & $f$ & $\%$ & $f$ & $\%$ & $f$ & $\%$ \\
\hline$\overline{\text { CRIs }}$ & 19 & 33.93 & 11 & 19.64 & 15 & 26.79 \\
\hline SRIs & 14 & 25.0 & 23 & 41.07 & 20 & 35.71 \\
\hline
\end{tabular}

Regarding the items always and occasionally employed by the teachers, it seems that selected response items are preferred more frequently in the written assessment of foreign language education. In return, the teachers who reported that they seldom and never use selected response items in their written tests outnumber those who stated that they seldom and never use constructed response items in these tests. All in all, it could be concluded that selected response items are preferred more frequently in the written assessment process of students' progress in foreign language education as opposed to the constructed response items, which conflicts with Kırkgöz and Ağçam (2012). This might result from the fact that selected response items are easier to prepare and more objective. Besides, they do not require much time for evaluation as the constructed response items. It might also stem from the structure of the tests administered at the end of each school year in Turkey. Keeping this in mind, the teachers might prefer these items as they want to create an atmosphere whereby students get prepared for the tests in concern. The following section is intended to outline the evaluation of research questions, implications for foreign language education and a few suggestions for further research.

\section{Conclusion}

The present study was set out to address four research questions to scrutinize primary school teachers' perceptions on testing and assessment in foreign language education as well as assessment types they use in the related process and types of questions they employ in their written tests. Accordingly, the first question investigated the perceptions of EFL teachers on language testing and assessment in primary education in Turkey. Most of the participants appreciate the importance and value of assessment in language classrooms, and state that they take students' in-class performance and their interest in homework assignments into consideration when evaluating their ultimate success in EFL classes. Besides, the majority report that they revise their lesson plans in accordance with the (undesired) exam results of the students.

The second question was intended to explore the assessment types used by these teachers in language testing and assessment in primary education in Turkey. Their responses have proved that pen-and-paper exams, performance tasks and in-class observation are the most frequently used assessment types while quizzes and project assignments are preferred more than $70 \%$ of the teachers, and oral exams and presentations are the least frequented types employed in assessing the success of these students.

The third question inspected their perceptions on core language skills in language testing and assessment in primary education in Turkey. The responses have revealed that speaking, vocabulary and grammar are considered the most significant skills while reading and writing are paid adequate care and listening receive least attention in assessing the success in language classrooms.

The last question was formed to see the types of questions used by EFL teachers in language testing and assessment in primary education in Turkey. In accordance with the responses, it is seen that fill-in and whquestions are the most frequently used question types in written exams in EFL classes. Matching, True/ False and Yes/ No Questions revealed the second mostly preferred types while Multiple Choice items constitute the least frequented category used in these exams.

To conclude, the study has displayed that speaking and vocabulary are paid much more attention than grammar by the EFL teachers working at state primary schools in Turkey. It has also shown that performance tasks, in-class observation and project assignments are considered significant regarding assessment in language classrooms in these schools, and that they are frequently used by the teachers in concern. These partly contradict the finding (teacher-centred/textbook-centred learning and grammar based testing) acknowledged in the report by British Council as one of the five factors that lead to the failure of Turkish students to speak/ understand English on graduation from High School'.

That learning is teacher-centred/ textbook centred or learner-centred is not within the scope of this study but its findings have made it clear that testing in EFL classes of $4^{\text {th }}, 5^{\text {th }}$ and $6^{\text {th }}$ graders are not largely grammar based; instead, performance-based assessment types and communication skills play a significant role in the language assessment of these students.

\section{Practical Implications}

Our study has shown that Turkish EFL teachers working at state primary schools mostly favoured traditional assessment types, and that existing assessment practices are teacher-oriented, mostly speaking and vocabulary based applications. This might have been triggered by such factors as curriculum requirements and existing classroom conditions (e.g. class size, time restriction), or that teachers regard traditional types as more reliable and applicable in comparison to the other types of assessment. More formative assessment types such as selfassessment and peer assessment might be suggested for assessing success in the language classrooms informing teachers that this kind of testing is more likely to decrease anxiety level of students in their attempt to learn a second/ foreign language. Last but not least, it should be kept in mind that teachers' educational perceptions are largely influenced by their perceptions. Therefore, efforts should be invested in order to help them develop positive perceptions on teaching and learning that will broaden their horizon allowing and encouraging them to employ appropriate assessment styles in their teaching. 


\section{Suggestion for Further Directions}

This study is confined to the investigation of EFL teachers' perceptions of language testing and assessment in primary education in Turkey. It is also confined to a limited number of participants (56) working at state primary schools in Turkey. Further studies might be conducted with a larger group of EFL teachers working at various state or private primary schools. Teachers' perceptions on language testing and assessment might be elicited through questionnaires and/ or structured or semi-structured interviews. The study might also be furthered to scrutinize perceptions of students attending primary schools on language testing and assessment in Turkey. The study is limited to the "reported" perceptions of EFL teachers on language testing and assessment in Turkey; therefore, a further study might explore whether these reported practices are reflected in real classroom settings.

As suggested by Shim (2009) little research has been done on the influence of head teachers, supervisors, policy makers and administrators on the use of assessment material employed in the schools. In this respect, the role of policy makers which might have influenced the assessment process of elementary school students' success in foreign language learning was totally ignored in the present study. So, it might be investigated in a further study.

\section{References}

Abdao, D., 2015. Principles and methods of assessment. Retrieved from https://abdao.wordpress.com/tag/formative-and-summativeassessment/.

Al-Nouh, N.A., H.A. Taqi and M.M. Abdul-Kareem, 2014. EFL primary school teachers' attitudes, knowledge and skills in alternative assessment. International Education Studies, 7(5): 68-84. View at Google Scholar $\mid$ View at Publisher

Angelo, T.A., 1995. Reassessing (and Defining) assessment. AAHE Bulletin, 48(3): 7-9. View at Google Scholar

Benitez, D., F. Questier and D. Perez, 2015. Students' experiential knowledge production in the teaching-learning process of universities. In M. Massaro \& A. Garlatti (Eds.), Proceedings of the 16th European Conference on Knowledge Management, University of Udine, Italy, 3-4 September 2015.

Bernstein, D.A., L.A. Penner, A. Clarke-Stewart and E.J. Roy, 2012. Psychology: An international discipline in context. California: Wadsworth.

Birgin, O. and A. Baki, 2009. An investigation of primary school teachers' proficiency perceptions about measurement and assessment methods: The case of Turkey. Procedia Social and Behavioral Sciences, 1(1): 681-1685. View at Google Scholar |View at Publisher

Brown, J.D. and T. Hudson, 1998. The alternatives in language assessment. TESOL Quarterly, 32(4): 653-675. View at Google Scholar $\mid$ View at Publisher

Chan, Y.C., 2007. Elementary school EFL teachers' beliefs and practices of multiple assessments in the Northern Taiwan. National Science Council Research Project (NSC 92-2411-H-152-006). Taipei: National Science Council

Cheng, L., T. Rogers and H. Hu, 2004. ESL/EFL instructors' classroom assessment practices: Purposes, methods, and procedure. Language Testing, 2 1(3): 360- 389. View at Google Scholar | View at Publisher

Dunn, L., C. Morgan, M. O'Reilly and S. Parry, 2004. The student assessment handbook. Abingdon: Routledge Falmer.

Elmore, R., 1996. Getting to scale with good educational practice. Harvard Educational Review, 66(1): 1-27. View at Google Scholar $\mid$ View at Publisher

Gattullo, F., 2000. Formative assessment in ELT primary (Elementary) classrooms: An Italian case study. Language Testing, 17(2): 278288. View at Google Scholar | View at Publisher

Goldstone, R.L., D. Landy and J.Y. Son, 2008. A well grounded education: The role of perception in science and mathematic. In M. de Vega, A. Glenberg, \& A. Graesser (Eds.), Symbols, embodiment, and meaning. Oxford Press. pp: 327-355.

Gould, M., 2014. The social media gospel. Collegeville, Minnesota: Liturgical Press. pp: 4-7.

Grobgeld, E., A. Teichman-Weinberg, E. Wasserman and B.M. Barchilon, 2016. Role perception among faculty members at teacher education colleges. Australian Journal of Teacher Education, 41(5): 6. View at Google Scholar $\mid$ View at Publisher

Halpern, D.F., D. Appleby, S.E. Beers, C.L. Cowan, J.J. Furedy, J.S. Halonen, C.P. Horton, B.F. Peden and D.J. Pittenger, 1993. Targeting outcomes: Covering your assessment concerns and need. In T. McGovern \& C. Baum (Eds.), Handbook for enhancing undergraduate education in psychology. Washington: American Psychological Association. pp: 23-46.

Haznedar, B., 2010. Foreign language education in turkey: Reforms, trends, and the teachers. Paper Presented at the International Conference on New Trends in Education and Their Implications, 11-13 November, 2010, Antalya-Turkey.

Haznedar, B., 2012. Foreign language education in turkey: Primary foreign language program. Boğaziçi University Journal of Education, 21(2): 15-28.

Horner, R.H., E.G. Carr, J. Halle, G. McGee, S. Odom and M. Worley, 2005. The use of single-subject research to identify evidence-based practice in special education. Exceptional Children, $71(2)$ : 165-179. View at Google Scholar $\mid$ View at Publisher

Kırkgöz, Y., 2007. English language teaching in Turkey: Policy changes and their implementations. RELC Journal, 38(2): 216-228. View at Google Scholar View at Publisher

Kırkgöz, Y. and R. Ağçam, 2012. Investigating the written assessment practices of Turkish teachers of english at primary education. Journal of Language and Linguistic Studies, 8(2): 119-136. View at Google Scholar

Könings, K.D., T. Seidel, S. Brand-Gruwel and J.J.G. van Merriënboer, 2014. Differences between students' and teachers' perceptions of education: Profiles to describe congruence and friction. Instructional Science, 42(1): 11-30. View at Google Scholar $\mid$ View at Publisher

Lindsay, P.H. and D. Norman, 1977. Human information processing: An introduction to psychology. New York: Academic Press.

Marzano, R.J., 1992. A different kind of classroom: Teaching with dimensions of learning. Alexandria, VA: Association for Supervision and Curriculum.

Mayring, P., 2000. Qualitative inhaltsanalyse grundlagen und techniken. 7th Edn., Weinheim: Deutscher Studien Verlag.

$\ddot{O} z$, H., 2014. Turkish teachers' practices on assessment for learning in the english as a foreign language classroom. Journal of Language Teaching and Research, 5(4): 775-785. View at Google Scholar | View at Publisher

Rea-Dickens, P., 2000. Classroom assessment. In T. Hedge (Ed.), Teaching and learning in the language classroom. Oxford, UK: Oxford University Press. pp: 375-401.

Robbins, S.P., 2009. Organizational behaviour in Southern Africa. 2nd Edn., South Africa: Pearson South Africa.

Saad, M.R.B.M., S.A. Sardareh and E.K. Ambarwati, 2013. Iranian secondary school EFL teachers' assessment beliefs and roles. Life Science Journal, $10(3)$ : 1638-1647. View at Google Scholar

Shim, M., 2009. An analysis of early childhood english education in terms of the integrated education. Unpublished PhD Dissertation, Ajou University, South Korea.

Spector, J.M. and A.H.K. Yuen, 2016. Educational technology program and project evaluation. New York: Routledge.

Wood, J.T., 2013. Interpersonal communication: Everyday encounters. 7th Edn., Boston: Wadsworth.

Yung, T., 2008. Factors affecting EFL teachers' use of multiple classroom assessment practices with young language learners. English Teaching \& Learning, 32(4): 85-123. View at Google Scholar 